\title{
Evaluation of bio-aerosols type, density, and modeling of dispersion in inside and outside of different wards of educational hospital
}

\author{
Ameneh Yousefzadeh ${ }^{1} \cdot$ Afshin Maleki $^{2}$ (1) Saeed Dehestani Athar ${ }^{2} \cdot$ Ebrahim Darvishi $^{2} \cdot$ Manochehr Ahmadi $^{3}$. \\ Ebrahim Mohammadi ${ }^{2} \cdot$ Van Tai Tang ${ }^{4} \cdot$ Rasoul Nassiri Kalmarzi $^{5} \cdot$ Hajar Kashefi $^{2}$
}

Received: 7 May 2021 / Accepted: 22 September 2021 / Published online: 3 October 2021

(C) The Author(s), under exclusive licence to Springer-Verlag GmbH Germany, part of Springer Nature 2021

\begin{abstract}
Exposure to bioaerosols in the air of hospitals is associated with a wide range of adverse health effects due to the presence of airborne microorganisms. Intensity and type of health effects depend on many factors such as the type, density, and diversity of bioaerosols in hospital environments. Therefore, identifying and determining their distribution in hospital environment contribute to reduce their adverse effects and maintain the physical health of patients and staff, as well as find the source of infections and possible allergies due to the presence of bioaerosols. Therefore, the present study was conducted to determine the type and concentration of the bacterial and fungal bioaerosols, and their distribution in the indoor and outdoor air of a teaching hospital to establish a reference for future studies or measures. The air samples were collected with a one-stage Anderson sampler and particle mass counter for a period of four months in the fall and winter of 2019. In total, 262 bacterial and fungal samples were collected from the air of the wards of Tohid Hospital, Sanandaj, Iran. Antibiotic resistance test, bacterial identification by PCR method, and modeling the dispersion of concentrations of bioaerosols were also conducted. In order to identify bacteria and fungi, some biochemical and molecular tests and microscopic and macroscopic characteristic methods were applied, respectively. The results showed that the highest and lowest densities of the bioaerosols were observed in lung and operating wards $\left(336.67\right.$ and $\left.15.25 \mathrm{CFU} / \mathrm{m}^{3}\right)$. Moreover, the highest and least concentrations of particles were seen in the emergency and operating wards, respectively. The most common fungi isolated from the hospital air were Penicillium (24.7\%), Cladosporium (23. 4\%), Aspergillus niger (13.3\%), and Aspergillus Flavus (11.4\%). Furthermore, the highest concentration of the isolated bacterium was Staphylococcus hemolyticus (31.84\%). Most bacteria showed the highest resistance to gentamicin. The overall average hospital air pollution to bioaerosols was slightly higher than the standards proposed by international organizations. Due to the high concentration of bioaerosols and particles in the studied hospital, providing suitable conditions such as temperature, humidity, proper ventilation, and intelligent air conditioning system using efficient ventilation systems, and restricting the entrance of wards can reduce airborne particles in hospital environment.
\end{abstract}

Keywords Particulate matter $\cdot$ Airborne pollutants $\cdot$ Microbial load $\cdot$ PCR, $\cdot$ Medical center $\cdot$ Antibiotic resistance

Responsible Editor: Diane Purchase

Afshin Maleki

maleki43@yahoo.com

1 Student Research Committee, Kurdistan University of Medical Sciences, Sanandaj, Iran

2 Environmental Health Research Center, Research Institute for Health Development, Kurdistan University of Medical Sciences, Sanandaj, Iran

3 Department of Microbiology, Faculty of Medicine, Kurdistan University of Medical Sciences, Sanandaj, Iran

4 Faculty of Environment and Labour Safety, Ton Duc Thang University, Ho Chi Minh City, Vietnam

5 Department of Internal Medicine, Faculty of Medicine, Kurdistan University of Medical Sciences, Sanandaj, Iran

\section{Introduction}

Suspended particles contain biological and non-biological substances that can be transported by air flow (Goudarzi et al. 2016; Sepahvand et al. 2016). Bioaerosols are defined as aerosols or any other gas containing a living component or particles released from a living organism. The size of bioaerosols varies from $0.001 \mu \mathrm{m}$ to about $100 \mu \mathrm{m}$ (Kim et al. 2018). In a general classification based on the nature of bioaerosols, they can be divided into the following three categories: a) viruses and parasites b) living organisms including bacteria and fungi c) parts of microorganisms or products derived from them such as spores, plant pollen, endotoxins and animal allergens (FröhlichNowoisky et al. 2016; Kim et al. 2018) 
Fungi and bacteria constitute a large range of microorganisms in hospital environments. The level and variety of biological pollution in hospital environments depend on various factors such as the number and activities of visitors, patients, design of hospital rooms, disinfection methods, dust load in the air and so forth (Aala et al. 2017; Saadoun et al. 2008). Today, the transmission of viruses and pathogenic bacteria is recognized as an important route for a wide range of nosocomial infections. According to studies, $10 \%$ of nosocomial infections are airborne infections and $16 \%$ of intensive care unit (ICU) infections are due to airborne pathogen transmission (Mirhoseini et al. 2016). Some recent studies have shown that up to $10-20 \%$ of all endemic nosocomial infections may be transmitted through airborne infections. Also, $11 \%$ of all deaths in low-income countries are owing to lower respiratory tract infection for indoor air pollution (Gizaw et al. 2016). Hospital buildings, as dynamic environments, may be affected by season, weather conditions, design and operation of indoor ventilation systems, moisture penetration, microbial load in the open air, and the number of residents, visitors, and human activities (Verde et al. 2015). In this case, hospital environments require special attention to ensure the health of indoor air quality (IAQ) for the protection of patients and healthcare staff against nosocomial infections and occupational diseases (El-Sharkawy and Noweir 2014).

In hospitals, Staphylococcus aureus and Streptococcus pyogenes are a global public health problem. These two species are common pathogens in hospitals that may cause severe invasive infections (Gizaw et al. 2016, Osadebe and Okounim 2020). Park et al. who assessed the levels of airborne bacteria, gram-negative bacteria, and fungi in hospital lobbies, stated that all the lobbies were infected by these microbial agents. (Park et al. 2013).

Antibiotic resistance is a major problem in the treatment and control of infections. Extensive use of antibiotics in recent years has resulted in some bacterial resistance to broadspectrum antibiotics from different groups; at present, the presence of multidrug-resistant strains of antibiotics (MDR) is the main problem in the treatment of bacteria such as Pseudomonas aeruginosa in important hospital wards like burns and intensive care (Adabi et al. 2015). Hence, in this study, the resistance of 11 types of bacteria isolated from indoor air to the antibiotics amoxicillin, cefixime, ciprofloxacin, azithromycin, gentamicin, doxycycline, and sulfamethoxazole were evaluated.

As the rate of nosocomial infections is directly related to the density and type of bioaerosols, determination of the type and density of these microorganisms is of particular importance (Massoudinejad et al. 2014). In the current research, the amount of airborne microorganisms inside the hospital was performed in the internal wards of men and women, infectious, lung, neurology, emergency, ICU, operating room, burns as well as air outside the hospital. Moreover, since suspended particles, PM1, PM2.5, PM4, PM7, PM10, are carriers of biological agents like bacteria and fungi, quantitative analysis of them and their relationship with microbial density is of great importance (Cao et al. 2014). Therefore, suspended particle matters were also detected. Furthermore, the modeling of the dispersion of bio-aerosols in different wards and identification of bacterial isolates by the PCR method were also determined.

\section{Materials and methods}

\section{Study area}

This research was conducted in one of the teaching hospitals (Tohid hospital) in the city of Sanandaj, Iran. The air inside and outside the hospital was sampled to measure bacterial and fungal aerosols as well as the amount of suspended particles, moisture and temperature. Monthly sampling was performed in two seasons of autumn and winter (twice in each season in three stations in each ward and three stations outside the hospital.

\section{Sampling method}

In this study, so as to determine the quantity and type of bacterial and fungal contaminants as well as particles the samples were taken from a number of wards inside the hospital (men's ward, women's ward, lung, neurology, infectious, ICU, burns, operating room, emergency) and the air outside the hospital. The sampling was performed in such a way that all wards of the studied hospital were covered. The sampling was performed in four times in autumn and winter. Inside the hospital, three stations were considered in each ward and in the air outside the hospital, three stations were considered. In order to evaluate and determine microbial airborne contaminants in the air of different wards, an Andersen one-stage sampler (Quick Take-30, SKC, USA) was used. This device consists of a biostage having 400 holes and a plate containing the culture medium placed in it. The flow rate of the sampling pump was 28.3 $\mathrm{L} / \mathrm{min}$ and the duration of sampling air inside and outside the hospital was selected using trial and error at different times for the flow rate to increase the accuracy of the results.

Finally, the sampling time was 20 and $5 \mathrm{~min}$ for bacteria and fungi, respectively. Also, the sampler was located at a height of $1.5 \mathrm{~m}$ above the ground and at a distance of more than $1 \mathrm{~m}$ from the walls and obstacles (Nunes et al. 2005). Regarding the samples taken from the hospital grounds, these samples were taken from a distance of at least $50 \mathrm{~m}$ from the streets.

Before the sampling, all devices were first washed in disinfectant solution ( $70 \%$ alcohol) and then autoclaved for $30 \mathrm{~min}$ at the standard temperature and pressure. Next, all items were transported in sterile packages to the hospital 
The culture medium used in this study contained bacterial agents: tryptic soy agar (TSA) and fungi: malt extract agar (MEA) containing the antibiotic chloramphenicol.

Particles and dust were measured by Particle Mass Counter (model: TES-5200). This device has the ability to measure particles in two modes: count mode to measure the number of particles in the sizes of $0.5,0.7,1,2.5,4,5,7$ and $10 \mu \mathrm{m}$ and mass mode to measure the volume density level in accordance with the standards PM1, PM2.5, PM4, PM7, PM10. At the same time, the measured volume or flow shows the sample air temperature in terms of ${ }^{\circ} \mathrm{C}$ or ${ }^{\circ} \mathrm{F}\left(10-40{ }^{\circ} \mathrm{C}\right)$ and the relative humidity $(20-20 \%)$ of the sample air. The flow rate is $2.83 \mathrm{~L} / \mathrm{min}$ or $0.1 \mathrm{CF} / \mathrm{min}$. In other words, the sampling time is $1 \mathrm{~min}$.

\section{Bacterial identification}

The collected samples were transferred to an incubator (35-37 ${ }^{\circ} \mathrm{C}$ ). After 40 to $56 \mathrm{~h}$ (average $48 \mathrm{~h}$ ), the culture medium containing the bacteria was examined, and the colonies formed on them were counted. In order to count the colonies, ocular and colony counter methods were used. For bacteriological examination, the cultured samples were taken out of the incubator and all the plates were tested for colony growth, morphology, color and appearance. For microscopic examination of bacteria as well as morphologically (cocci or bacilli) some biochemical tests such as gram staining, catalase, oxidase, urease, OF and IMViC were performed. It should be pointed out that some biochemical tests such as gram staining, catalase, urease and oxidase were repeated for each type of colony two to three times to achieve accurate results.

\section{Evaluation of antibiotic-resistant bacteria}

In this study, the antibiotic resistance test was performed for 18 types of the bacteria isolated from the air of the different wards of the hospital. The Kirby-Bauer disk diffusion method was used to determine the antibiotic-resistant isolates. The bacterial concentration was adjusted at 0.5 McFarland standard $\left(10^{8} \mathrm{CFU} / \mathrm{ml}\right)$ and then diluted 100 -fold to $10^{6} \mathrm{CFU} / \mathrm{ml}$. Inoculation of the $\mathrm{MH}$ plates was carried out by sterile swab dipped into the diluted suspension followed by spreading the plates and placement of the antibiotic disks $(10 \mu \mathrm{g} / \mathrm{disc})$ on the surface of the agar. To determine whether the bacteria were susceptible, intermediately resistant, or resistant, an edge-toedge measurement across the inhibition zone over the center of the disk was carried out. The test was focused on seven main classes of antibiotics: penicillins, cephalosporins, macrolides, fluoroquinolones, sulfonamides, tetracyclines and aminoglycosides. Antibiotics including amoxicillin, azithromycin, ciprofloxacin, cefixime, doxycycline, gentamycin, and sulfamethoxazole were tested as a representative of each class.

\section{Bacterial identification by PCR method}

The total genomic DNA of the bio-aerosol samples was extracted by the standard phenol-chloroform method as described elsewhere (Krumins et al. 2014). UV spectrophotometry was used for the quantitative and qualitative analysis of the extracted DNAs at 260 and $280 \mathrm{~nm}$, respectively. 16S ribosomal-ribonucleic acid polymerase chain reaction (PCR) was applied for bacterial identification in the culture-positive samples. Universal oligonucleotides primers specifically designed for detection of 16S rRNA gene region were used (Mulla et al. 2018): forward: 27f (5'-AGAGTTTG ATCMTGGCTCAG-3') and reverse: 1492R (5'GGTTACCTTTGTTACGACTT-3'). For amplifications of $16 \mathrm{~S}$ ribosomal-DNA, reaction mixtures contain around $100 \mathrm{ng}$ of template DNA, $12.5 \mu \mathrm{L}$ of $2 \mathrm{x}$ PCR master mix containing appropriate PCR buffer, $2.5 \mathrm{mM}$ concentration of each dNTPs, 0.2 units/ $\mu$ l Ampliqon Taq DNA polymerase, $1.5 \mathrm{mM}$ of $\mathrm{MgCl}_{2}$ and a $20 \mathrm{pmol}$ of each forward and reverse PCR primers in a total volume of $25 \mu 1$ were prepared. In each PCR run, a negative control consisted of all PCR components, except for template bacterial DNA. The PCR conditions were as follows: after $5 \mathrm{~min}$ initial denaturation step at $94{ }^{\circ} \mathrm{C}, 33$ cycles of denaturation for 30 seconds at $94{ }^{\circ} \mathrm{C}$, annealing for $30 \mathrm{~s}$ at $55^{\circ} \mathrm{C}$, and extension for $90 \mathrm{~s}$ at $72{ }^{\circ} \mathrm{C}$, followed by a final extension for $10 \mathrm{~min}$ at $72{ }^{\circ} \mathrm{C}$ were run in a thermal cycler machine (Biometra, Germany). The amplification products were electrophoresed in 1.5\% agarose gel, containing safe stain (Sinaclon ${ }^{\mathrm{TM}}$, Iran), at TBE and visualized using a UV transilluminator.

The PCR Products were gel purified by QIAquick PCR purification kit and Sanger sequencing was done by Microsynth (Switzerland). Sequence editing and assembly were done by DNA Dragon 1.6.0 (http://www.dna-dragon. $\mathrm{com} /$ ). Multiple sequence alignment was carried out by the Clustal W method (Thompson 1994) in MEGA X (MEGA and Evolution).

\section{Fungal identification}

The fungal samples were incubated at 25 to $27^{\circ} \mathrm{C}$ for $72 \mathrm{~h}$. Next, the number of colonies on the plates was counted. For the initial differential identification of fungi, their macroscopic features including surface and back staining of the colonies and their microscopic characteristics including shape, size and location of spores were used.

\section{Modeling the dispersion of concentrations of bio- aerosols in different wards}

Modeling methods are commonly applied to project the dispersion and distribution of contaminants in environments. SURFER is a contouring and $3 \mathrm{D}$ surface mapping software 
program running under Microsoft Windows. This software quickly and easily converts data into outstanding contour, surface, wireframe, vector, image, shaded relief, and post maps. SURFER is a data dispersion modeling software, which can be applied in different areas. This software can predict and test data using the power training from input data. The data dispersion in this method is determined on the basis of different counters and layers of data. In this method, the data dispersion and their scale are determined by the coloring. In this study, $70 \%$ of the data were used for training the networks, $30 \%$ were used for testing the software and predictive model.

\section{Statistical analysis}

Pearson correlation coefficient at a significant level $(\alpha=0.05)$ was used to establish the relationship between the bacteria and fungi concentrations in the air and the parameters such as temperature, wind speed and direction, moisture percentage, number of suspended particles. Meanwhile, the KruskalWallis test was used to determine the possible relationship between the bioaerosol concentration and the change of seasons and locations.

\section{Results and discussion}

In hospital environments, various factors such as temperature, relative humidity, hospital building design, ventilation system, and indoor population density and disinfection methods can affect the concentration of air pollutants (Mousavi et al. 2019). In this study, a total of 262 samples of bacteria and fungi from 10 hospital wards were examined. As a result, 14 bacterial species and 12 fungal species were identified.

\section{Particle distribution in different wards of the hospital}

Particle density in different wards of the hospital is influenced by factors such as the number of beds in each room, the number of patients in the hospital room, the rate of ventilation, the number of staff and the proximity to a street (Shokri et al. 2016). Due to the effect of particles on the density of bacterial and fungal bioaerosols, the sampling time of suspended particles was timed to coincide with the fungal and bacterial sampling. The observations of this study showed that the average concentration of particle in about $90 \%$ of the hospital wards and ambient air was higher than those reported by the 24-hour World Health Organization (WHO) and United States Environmental Protection Agency (USEPA) standards. Particles and their size are key determinants of pathogen transport, aeration, and transmission. Infectious respiratory through particles depends on the type and frequency of respiratory activity, type and location and the load of pathogens. Additionally, relative humidity, particle accumulation, and mucosal properties affect the size of the excreted particles and subsequent transfer (Gralton et al. 2011).

In this study, the effect of temperature as one of the meteorological parameters on the concentration of suspended particles was investigated. Based on the results, the average temperature of the hospital wards was $24.77^{\circ} \mathrm{C}$. The Centers for Disease Control and Prevention and Healthcare Infection Control Practices Advisory Committee (HICPAC) recommend temperatures of $21-24$ and $23-27^{\circ} \mathrm{C}$, respectively, in winter and summer for most wards of hospitals (Chinn and Sehulster 2003).

In the infectious ward, in all concentrations studied, temperature and particle concentration had a significant relationship and a positive correlation coefficient; for instance, with increasing temperature in the infectious ward, the concentration of suspended particles increased. This increase in the concentration of particles in the ICU and infectious wards can be due to reasons such as the large number of patients admitted to the wards, high traffic of companions, use of non-sterile personal equipment by companions and patients, lack of a proper ventilation system, and type of disease. Therefore, temperature can be considered as a factor in increasing the concentration of particles. In Table 1, similar results were achieved by Wang et al.

According to the results, there was no direct and significant relationship between moisture and particle concentrations in different diameters in all the wards. The most polluted part in terms of the presence of particles in different sizes was related to the emergency ward for reasons such as a wide range of patients and their congestion in the emergency ward compared to other wards or high traffic of clients, lack of hygiene, smoking and inadequate ventilation. Unlike, it was found that the operating room befitted from the best conditions, which can be due to the high level of health standards such as limited traffic, fewer patients, closed entrance to the other wards and proper ventilation, sterilization and disinfection of surfaces and premises. Moreover, similar observations were shown by Shokri et al. (Table 1).

\section{Fungi}

According to the data from Table 2, the lung ward was the most infected part of the hospital in terms of the presence of airborne fungi. Even so, in this section, the number of colonies was higher than $200 \mathrm{CFU} / \mathrm{m}^{3}$. Also, the operating room with the lowest number of grown colonies had the best air quality among the other wards of the hospital. The low level of pollution in the operating room can be due to the importance and sensitivity of this ward compared to other wards. The hospital has a high level of compliance with health standards such as limited traffic, fewer patients, frequent purification of room air by high-efficiency particulate air (HEPA) filters, suction of 
Table 1 Results of previous studies

\begin{tabular}{|c|c|c|c|}
\hline Title & Year & Main Results & Reference \\
\hline $\begin{array}{l}\text { Hospital indoor PM10/PM2. } 5 \text { and } \\
\text { associated trace elements in } \\
\text { Guangzhou, China }\end{array}$ & 2009 & $\begin{array}{l}\text { The results showed that indoor PM2.5 } \\
\text { levels with an average of } 99 \mu \mathrm{g} / \mathrm{m}^{3} \\
\text { were significantly higher than the out- } \\
\text { door PM } 2.5 \text { standard }\left(65 \mathrm{~g} / \mathrm{m}^{3}\right) \text { as } \\
\text { recommended by the EPA. }\end{array}$ & $\begin{array}{l}\text { (Wang } \\
\text { et al. } \\
\text { 2006) }\end{array}$ \\
\hline $\begin{array}{l}\text { Evaluation of hospital wards indoor air } \\
\text { quality: the particles concentration }\end{array}$ & 2016 & $\begin{array}{l}\text { The mean } 24 \mathrm{~h} \text { concentrations of PM10, } \\
\text { PM2.5 and PM0.3 were, respectively, } \\
83.09,21.47 \text { and } 1.6 \mu \mathrm{g} / \mathrm{m} 3 \text { at indoor }\end{array}$ & $\begin{array}{l}\text { (Shokri } \\
\text { et al. } \\
\text { 2016) }\end{array}$ \\
\hline
\end{tabular}

Profiles and seasonal distribution of airborne fungi in indoor and outdoor environments at a French hospital

Antibiotic resistant airborne bacteria and their multidrug resistance pattern at University teaching referral Hospital in South Ethiopia

Microbiological Surveillance of Operation Theatres: Five Year Retrospective Analysis from a Tertiary Care Hospital in North India

Prevalence and susceptibilities of Coagulase Negative Staphylococci isolated in health care workers in a millitary hospital, Kermanshah parts of the hospital. The highest concentrations were observed in men cardiac, women internal, and women cardiac wards. As a result, a significant positive relationship as observed between temperature and humidity with the concentration of suspended particles in the mentioned sizes in the ambient air inside the wards.

2009 The mean viable fungal load was 122.1 $\mathrm{CFU} / \mathrm{m}^{3}$ in outdoor air samples, and 4.1 and $3.9 \mathrm{CFU} / \mathrm{m}^{3}$ in samples from adult and pediatric hematology units, respectively. In outdoor samples, Cladosporium was the dominant genus $(55 \%)$ while in the clinical units, Penicillium sp. (23 to 25\%), Aspergillus sp. (15 to $23 \%)$ and Bjerkandera adusta (11 to $13 \%$ ) were the most frequently recovered airborne fungi.

2017 Acinetobacter species showed a high rate of resistance for trimethoprim-sulfamethoxazole, gentamicin (78.2\%) and ciprofloxacin $(82.6 \%), 28(38.9 \%)$ of $S$. aureus isolates were meticillin resistant, and 7.5\% Enterococci isolates of were vancomycin resistant. Also, $75.3 \%$ of all bacterial pathogens were multi-drug resistant. Among them, $74.6 \%$ were Gam positive and $84 \%$ were Gram negative.

The results showed that the lowest and highest rates of bacterial colony unit (CFU) was shown $17200 \mathrm{CFU} / \mathrm{m}^{3}$ in eye surgery and emergency wards, respectively. And, 15 out of 64 samples taken were positive; th predominant Isolates were as follows: $4 \mathrm{CONS}, 4$ micrococci, 3 Bacillus, 2 Acinetobacter, 1 Enterobacter, 1 Pseudomonasm.

$201562 \%$ of the isolates were CNS strains (Staphylococcus negative coagulase). The highest resistance in these strains (epidermidis, saprophyticus, hemolyticus and hominis) against oxacillin: 90, 94, 89 and $100 \%$, and gentamicin: $86,81,65$ and $100 \%$, respectively, and the highest susceptibility was observed in mupirocin $(100,100,100$ and $100 \%)$, vancomycin $(85,88,78$ and $100 \%)$.
(Solomon et al. 2017)

(Najotra et al. 2017)

(Dadashi et al. 2015) 
Table 2 Mean and standard deviation of fungal pollution load $\left(\mathrm{CFU} / \mathrm{m}^{3}\right)$ in the hospital

\begin{tabular}{|c|c|c|c|c|c|c|c|c|c|c|}
\hline Ward & $\begin{array}{l}\text { Internal } \\
\text { men }\end{array}$ & $\begin{array}{l}\text { Internal } \\
\text { women }\end{array}$ & Lung & Neurology & Infectious & Burn & ICU & $\begin{array}{l}\text { Operating } \\
\text { room }\end{array}$ & Emergency & $\begin{array}{l}\text { Outside } \\
\text { air }\end{array}$ \\
\hline Average $\left(\mathrm{CFU} / \mathrm{m}^{3}\right)$ & 62.20 & 124.25 & 223.09 & 154.09 & 63.27 & 42.70 & 55.55 & 0.42 & 106.42 & 52.73 \\
\hline $\begin{array}{l}\text { Standard Deviation } \\
\quad\left(\mathrm{CFU} / \mathrm{m}^{3}\right)\end{array}$ & 26.72 & 283.79 & 164.98 & 25.38 & 12.66 & 24.07 & 13.03 & 0.50 & 71.23 & 27.51 \\
\hline
\end{tabular}

outside air by exhaust fan and sterilization of equipment and surfaces by ultraviolet devices.

In this study, the number of colonies detected in different wards of the hospital was higher than the standard recommended by the WHO (50 colonies). Although the health hazards posed by bioaerosols have been identified and proven, no specific permissible limits are recommended for this category of airborne pollutants. The large number of hospital beds and the consequent increase in the number of patients and visitors, as well as the inadequate ventilation system in some patients' rooms and the poor quality of indoor air, are among the factors providing conditions for growth and proliferation of fungal spores (Azizifar et al. 2009; Kamali Sarwestani et al. 2017). Some clients' activities such as talking, walking in wards, sneezing and coughing consecutively also increase the spread and consequently cause the load of bioaerosols in the air of the hospitals to increase. Among the fungal species observed in the study, Penicillium, Cladosporium, Aspergillus Niger and Aspergillus Flavus were the most abundant, respectively. The findings of the study by Kotgire also showed that Aspergillus spp. was one of the dominant fungal species identified (Kotgire et al. 2020). Similarly, Cladosporium, Penicillium and Aspergillus were reported as the dominant species isolated from hospital environments. Furthermore, in Table 1, the results of a study by Sautour et al. have been stated, which accord with those obtained in the current research.

The reason for the predominant presence of these three types of fungal species in the air inside the hospital can be stated that Penicillium, Cladosporium and Aspergillus fungi have high growth ability in different climatic conditions and by producing small, light spores remain in air. Conidia spores of these fungi also have an outer layer rich in hydrophobic protein, which leads to their further suspension in the air. These fungi have the ability to supply the carbon and hydrogen that they need from a variety of sources, allowing them to survive longer in a variety of conditions. However, other fungi such as Alternaria and Ulocladium and some other species produce smaller, larger and heavier spores that tend to settle faster and are found at different levels (Alangaden 2011; Vonberg and Gastmeier 2006).

The most and least fungal species observed in the present study were Penicillium and cranosporium and yeasts and scopolariopsis (Fig. 1). Several species of fungi have been observed in some stations. Fungal species of Aspergillus flavus, Alternaria, Penicillium, and Geotrichum were mostly observed in the burn ward. In the ICU ward, Alternaria, Aspergillus niger and Ulocladium were mostly observed. Furthermore, in the emergency ward, the most observed species were Cladosporium, Penicillium, Rhizopus and Ulucladium.

\section{Bacteria}

Bacterial densities in the hospital wards ranged from 3.75 to 214.2 CFU $/ \mathrm{m}^{3}$. According to the results presented in Table 3, men's ward and operating room with an average of $148 \pm 65$ and $14.83 \pm 16.05 \mathrm{CFU} / \mathrm{m}^{3}$ had the highest and lowest levels of contamination load, respectively. The main reasons can be the high level of health standards in the operating room compared to other hospital wards, as well as disinfection and proper ventilation.

It should be noted that the average density of bacterial bioaerosols in the men's and women's wards, lungs and burns was higher than the standard recommended by the WHO (100 $\mathrm{CFU} / \mathrm{m}^{3}$ ) (Fig. 2). According to the study by Valedeyni Asl et al., the density of bacterial bioaerosols in the air of Ardabil teaching hospitals was higher than the standards suggested by the WHO and USEPA (Valedeyni et al. 2018). Factors such as population density, ventilation, and health conditions of the building and the type of hospitalized patients, the presence of companions and staff can increase the density of bacteria compared to the proposed standard (Valedeyni et al. 2018).

Considering that Tohid Hospital in Sanandaj is an educational and medical center, it can be said that one of the reasons for the high density of bacterial bioaerosols in this hospital, in addition to the high volume of patients, can be the presence of many students. In Masoudinejad's study, a significant linear correlation was observed between patients and population density with the concentration of bacteria, which showed the larger the population, the higher the number of bacteria in the air (Massoudinejad et al. 2015). Also, Solomon et al. reported similar results in their research (Table 1).

Environmental parameters are one of the factors affecting the microbial population in hospital environments. Due to the fact that temperature changes in the studied areas were in the small range (24 to $25 \%$ ), it did not have a significant effect on 
Fig. 1 Frequency distribution of fungal species isolated in different wards of the hospital

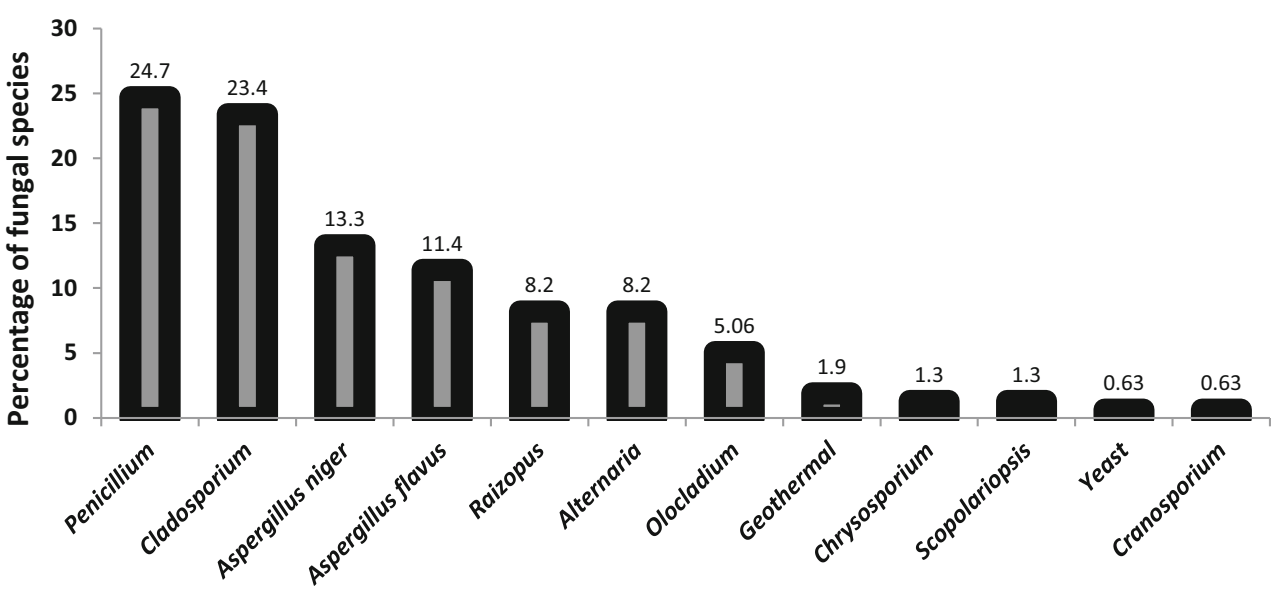

Different fungal species the concentration of bacteria. Also, the lack of correlation between the percentage of relative humidity and the number of bacteria in this study can be attributed to the small range of relative humidity changes $(23-27 \%)$ at the sampling points, which was 40 to $60 \%$ less than the proposed standard (Rafiee et al. 2018).

Since only floors, walls and some pieces of equipment are washed with disinfectants, the humidity of the air can increase due to washing, which facilitates the growth and persistence of microorganisms. On the other hand, if air conditioning is used in hospitals, it can reduce the humidity; because humidity is effective in the growth of bioaerosols and if air conditioning is used, bioaerosols that are in the outside air do not penetrate into the indoor environment, thereby reducing amount of indoor air pollution. As it turns out, different findings have been presented regarding the effect of temperature and humidity on the growth of bacteria in the air of hospitals, which requires more and more detailed studies in this field.

It was found that there was no significant relationship between the number of particles observed in different sizes and concentrations and the number of bacteria observed. That is,

Table 3 The mean of bacterial number observed in each ward

\begin{tabular}{llll}
\hline Ward & Average & Standard deviation & $\mathrm{p}$ \\
\hline Internal men & 148.00 & 65.154 & 0.071 \\
Internal women & 142.00 & 54.513 & \\
Lung & 113.58 & 37.378 & \\
Neurology & 92.66 & 28.053 & \\
Burn & 133.50 & 39.877 & \\
ICU & 90.33 & 18.712 & \\
Infectious & 100.08 & 99.235 & \\
Operating room & 14.83 & 16.059 & \\
Emergency & 38.91 & 20.887 & \\
Outside air & 84.50 & 59.046 & \\
\hline
\end{tabular}

particle concentrations and different particle sizes had no effect on the microbial load. The findings of this study are inconsistent with some previous studies. Mirhosseini et al., for example, reported that there was a significant relationship between 1 to $5 \mu \mathrm{m}$ particles and the density of bacterial bioaerosols in the surgical and ICU wards (Mirhoseini et al. 2015).

According to the results of differential tests, most of the bacteria isolated from the air of the wards in Tohid Hospital was Staphylococcus hemolyticus(Fig. 3). In Table 1, similar results were achieved by Solomon et al.

Staphylococci are among the opportunistic microorganisms that are detected in most areas, and since they are part of the natural flora of the skin and nose, it seems that their high rate in this study was because of the increase in population, especially during the presence of companions. Coagulasenegativestaphylococci include species of the genus Staphylococcus that lack the coagulase enzyme, and the most important species are Staphylococcus epidermidis, Staphylococcus saprophyticus, and Staphylococcus hemolyticus. These species are not only highly toxic, but also an important cause of infections in high-risk groups.

Staphylococcal infections can be transmitted through contact with an infected person or the patient's belongings, including clothing, towels, and bedding. The staff of hospitals are the most important and common carriers of them, from one sick person to another (Dadashi et al. 2015). Staphylococcus hemolyticus is the second most common coagulasenegativestaphylococcus as a pathogen in normal valvular endocarditis, septicemia, bacteremia, bone and joint infections, urinary tract infections, wound infections, and opportunistic infections. Unlike other CoNS, Staphylococcus hemolyticus is resistant to vancomycin (Sivagnanasundaram et al. 2019).

Bacillus was one of the bacteria identified in the hospital wards. The ability to form spores enables Bacillus species to tolerate harsh environmental conditions and conventional disinfection methods. Some bacilli are part of the opportunistic natural flora of the human gastrointestinal tract and are 
Fig. 2 The percentage of bacterial colonies of the sampling points in different surfaces: EU GMP standard

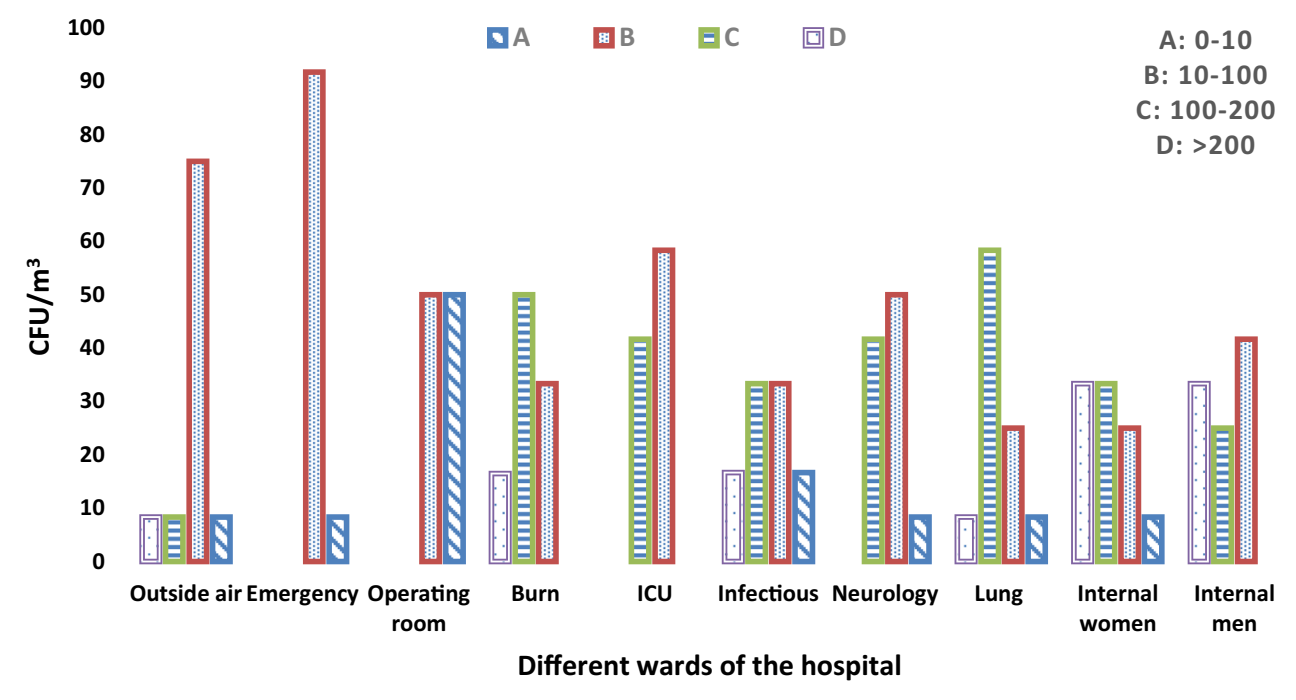

dangerous to immunocompromised patients such as those with AIDS and diabetes. Micrococcus luteus is also known as a nosocomial pathogen and causes pneumonia, endocarditis, meningitis and intracranial hemorrhage (Naddafi et al. 2009; Sivagnanasundaram et al. 2019).

In this study, Escherichia coli was less common than Staphylococcus, Bacillus, and Pseudomonas. It has been documented that Escherichia coli is involved in the development of diseases such as urinary tract infections, sepsis, pneumonia, gastroenteritis, and meningitis (Sivagnanasundaram et al. 2019).

According to the results, the total average of bioaerosols in this hospital was $184.38 \mathrm{CFU} / \mathrm{m}^{3}$. Based on the findings presented in Fig. 4, the highest density of bioaerosols was in the lung ward $\left(336.67 \mathrm{CFU} / \mathrm{m}^{3}\right)$ and the lowest was in the operating ward $\left(15.25 \mathrm{CFU} / \mathrm{m}^{3}\right)$. Following that, the women's ward and then neurology ward had the highest pollutant density.

\section{Evaluation of bacterial resistance to antibiotics}

The results of antibiotic resistance of 18 common bacteria detected in this study have been presented in Table 4. Among them, the highest drug resistance was observed in Staphylococcus hemolyticus and aureus. Staphylococcus hemolyticus showed resistance to five types of GM-CPAZM-AMX-CFM antibiotics.

Staphylococcus aureus is a ubiquitous organism and has a high potential for causing various diseases in humans owing to its high resistance to adverse environmental conditions. The development of resistance to various antibiotics in strains of
Fig. 3 Frequency distribution of different bacteria isolated in this study

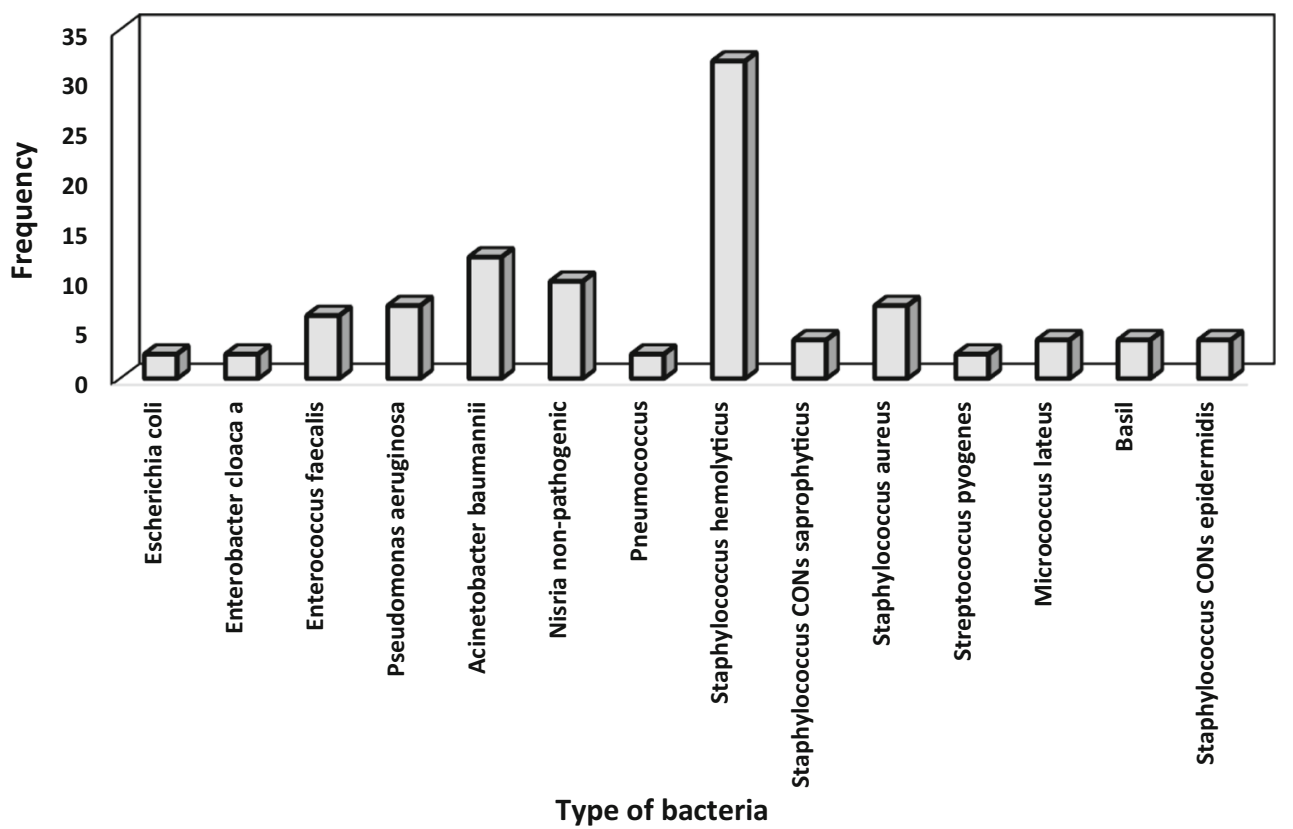


Fig. 4 General density of bioaerosols in each ward of the hospital $\left(\mathrm{CFU} / \mathrm{m}^{3}\right)$

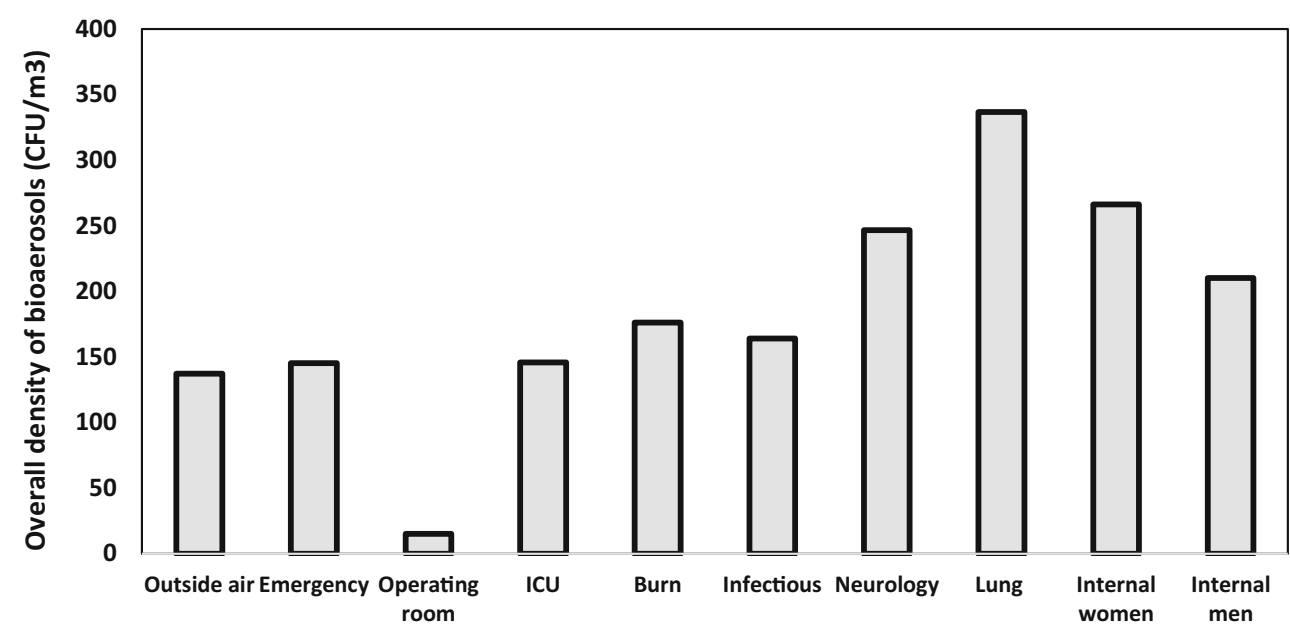

Different wards of the hospital

\begin{tabular}{ll}
\hline Type of bacteria & Antibiotic resistant \\
\hline Staphylococcus hemolyticus & GM- CP- AZM- AMX- CFM \\
Staphylococcus aureus & GM - AMX- CFM \\
Pneumococcus & SXT- CFM- GM \\
Staphylococcus CONs (epidermidis) & CP- GM \\
Staphylococcus CONs (Saprophyticus) and Staphylococcus & CFM \\
$\quad$ CONs (Epidermidis) and Bacillus & \\
Lateus micrococcus & AMX \\
Streptococcus pyogenes & GM \\
\hline
\end{tabular}

Staphylococcus aureus causes many problems in the treatment of diseases related to these microorganisms; thus, it is necessary to know the pattern of resistance of these

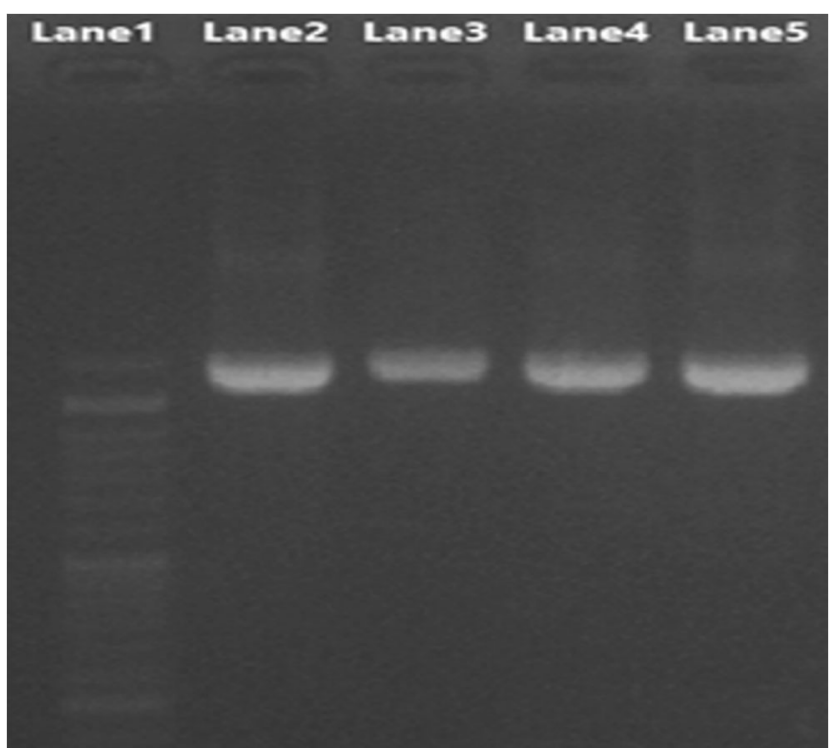

Fig. 5 Agarose gel electrophoresis of the samples amplified by the PCR method microorganisms in the treatment of related diseases (Saha et al. 2008). Antibiotic resistance of Staphylococcus aureus to GM-AMX-CFM antibiotics has been observed. In the study by Saadat et al., the highest resistance of Staphylococcus aureus to amoxicillin was found (Saadat et al. 2014), which is close to the findings of this study. Also, Staphylococcus epidermis was resistant to CP, GM and CFM. Moreover, similar results were obtained by Dadashi et al. and Najotra et al. (Table 1).

According to the findings of this study, the bacteria were most resistant to the antibiotic gentamicin ( $70 \%)$, followed by cefixime, amoxicillin and ciprofloxacin, respectively. Based on the results of this study, while identifying the underlying factors and appropriate measures to control antibiotic-resistant bacteria, it is recommended for coagulase-negative strains of Staphylococcus, especially species such as Staphylococcus hemolyticus to avoid prescribing high-resistance antibiotics such as gentamicin, cefixime, amoxicillin, and ciprofloxacin to these strains. It has been found that staphylococcus aureus is resistant to methicillin, aminoglycosides, macrolides, tetracycline, chloramphenicol, and linocosamides. Several mechanisms including multidrug efflux pumps and enzymatic inactivation of antibiotics are recognized for multidrug-resistant (MDR) of bacteria (Nikaido 2009). 

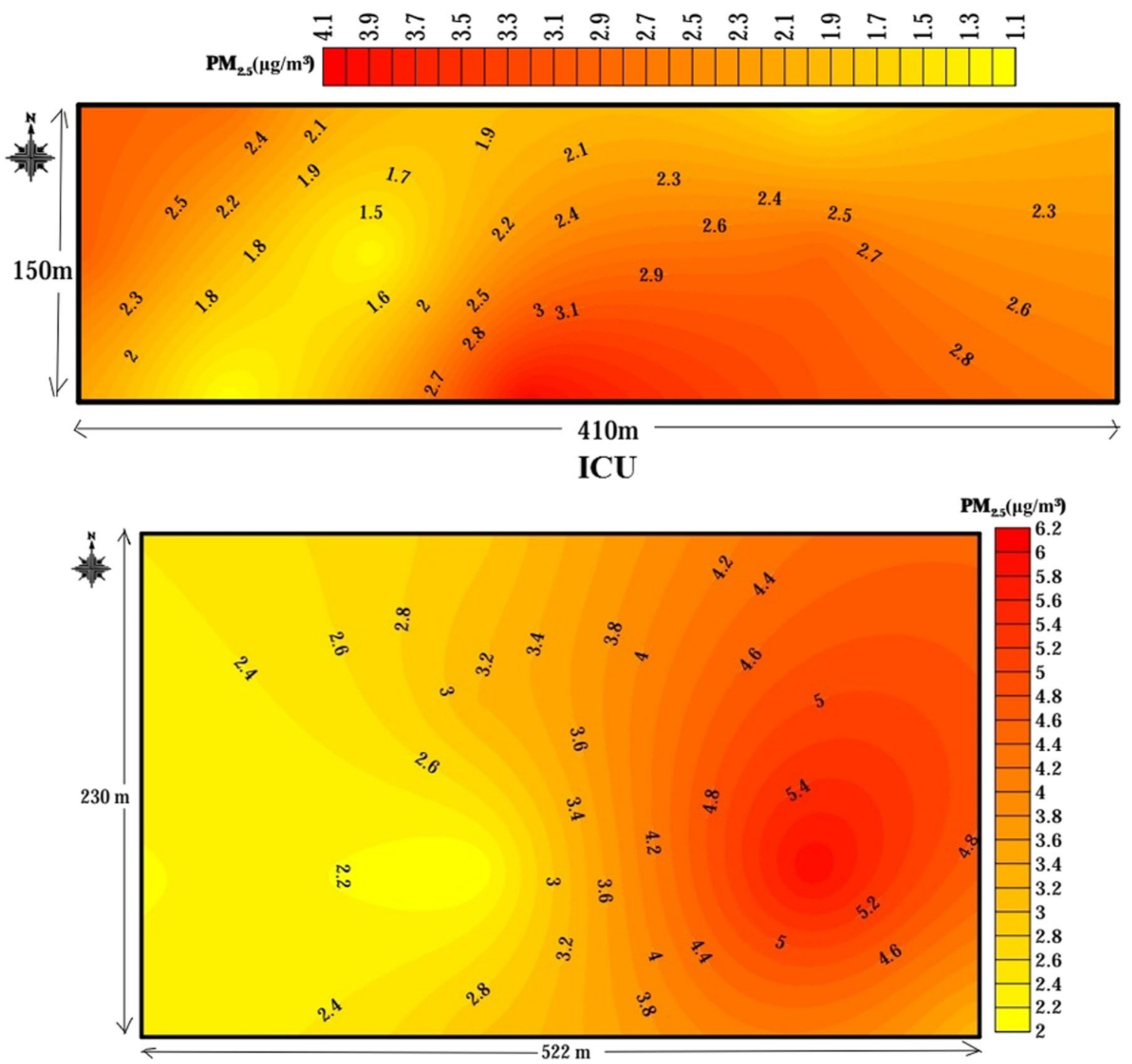

Infectious

Fig. 6 Possible dispersion of particles in each ward of the hospital

In this study, the PCR assay was performed for two samples of the bacteria that had the highest resistance and the highest presence among the identified bacteria. Sample number one was resistant to five types of antibiotics (ciprofloxacin, gentamicin, azithromycin, amoxicillin, cefixime) and sample number two was resistant to four types of antibiotics (gentamicin, azithromycin, amoxicillin, cefixime). The results of the molecular PCR test for both samples showed Staphylococcus hemolyticus. The reason for selecting these two samples was the highest resistance to antibiotic discs, the highest frequency and repetition among the samples taken during the study, as well as different appearance characteristics. NCBI nucleotide BLAST search (http://blast.ncbi.nlm.nih.gov/Blast.cgi) showed that sequences shared highest identity with Staphylococcus haemolyticus, Bacillus subtilis, Bacillus licheniformis (Fig. 5).
The amplification products were run on $1.5 \%$ gel of agarose (stained with Sinaclon ${ }^{\mathrm{TM}}$ safe stain) in an electrophoresis tank. Lane 1 indicates DNA Ladder Marker 100bp, Lane 2-5 indicate the amplified 16S rRNA gene of the bacterial isolate samples (S1-S4).

Currently, bacterial identification methods for bioaerosols include culture-dependent, sequencing of $16 \mathrm{~s}$ or $18 \mathrm{~s}$ rDNA and quantitative PCR techniques. Each one has its own advantages and disadvantages. Culture-dependent methods that allow the growth of only target bacteria normally find up to a maximum of $15 \%$ of all available bacteria in bioaerosol media (Wéry et al. 2014). On the other hand, PCR and subsequent $16 \mathrm{~s}$ rDNA sequencing are more powerful than culturing of bacteria as it identifies all viable and dead organisms. In our study, we performed sequencing of 16 s only for cultivated and more specifically antibiotic resistance of bacterial bioaerosols. 
Fig. 7 Arrangement of patient beds and ventilator outlets in the ICU

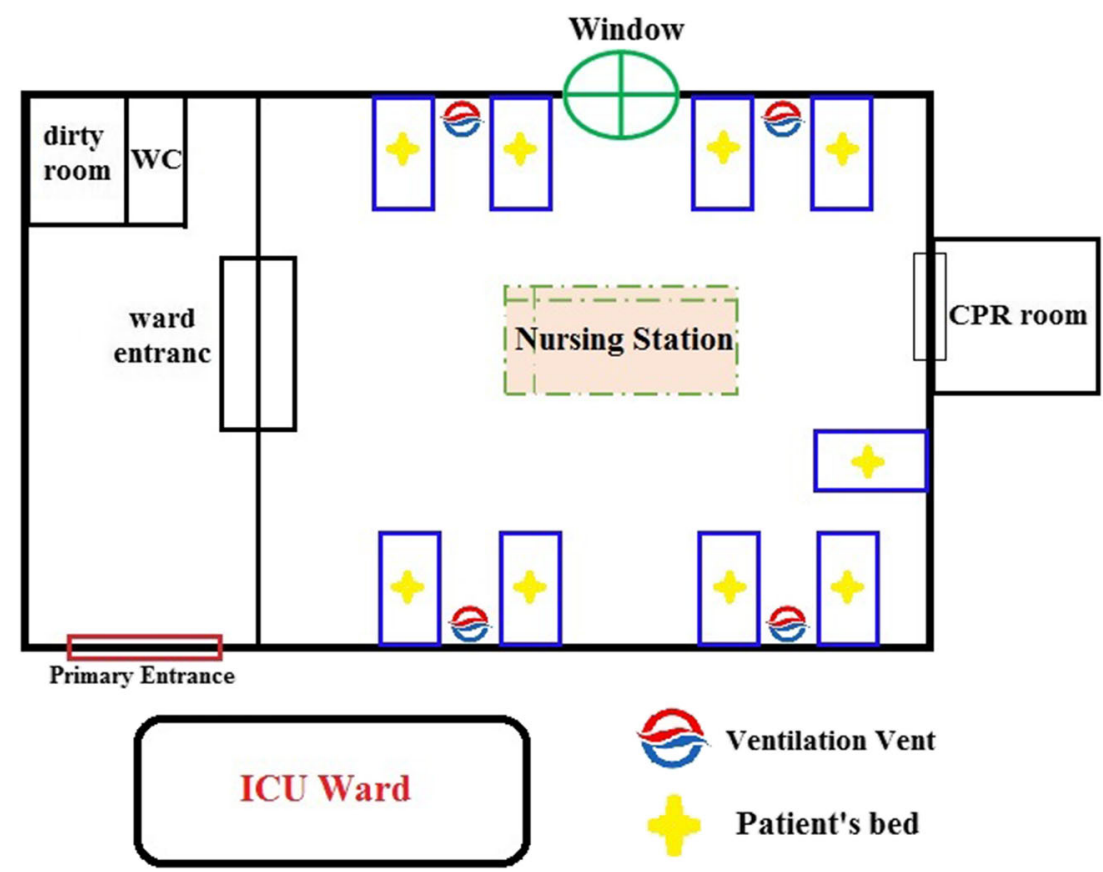

Therefore, we may not have had a chance to find all bioaerosol contents and this was the main drawback of our study.

\section{Modeling the dispersion of pollutants using SURFER software}

Maps prepared based on data from particle measuring stations in lung, neurology, infectious and open air wards showed that the emission and concentration of pollutants in the eastern parts had a higher dispersion. In other areas, including burns, ICU, emergency and men's and women's wards, the distribution of pollutants in all measuring stations in these areas was high. According to the results, the entrance of the infectious ward (east side) had the highest particle density, which can be due to the location of the waiting room at the entrance of the ward and high traffic in these areas (Fig. 6). However, the distribution of pollutants in other wards was evenly distributed.

Figure 7 shows the relative position of the various devices and parts within the ICU, including the patient bed, the nursing station, the air conditioner outlet/ventilator, and other features that can help to understand the concept of Figs. 6, 8, and 9.

Counter curves on the maps related to the distribution of bacteria in the hospital wards showed that in the men's and women's wards, the concentration of bacteria in the stations located in the northern and central parts of the wards was higher than the southern parts. The number of bacteria in the operating room was measured in the range of $2-36 \mathrm{CFU} / \mathrm{m}^{3}$. The counter curve numbers show that the bacterial dispersion was lower in most parts of the measuring stations and the less contour lines in the section. The central part shows the high concentration of bacteria. In the previous sections, it was stated that the lowest bacterial density was in the operating room.

In the intensive care unit, bacterial densities were measured in the range of $72-128 \mathrm{CFU} / \mathrm{m}^{3}$, and counter curves in the bacterial spreading map in this ward showed that bacterial densities were measured at the measuring points in the western part of the ward, which is located at the entrance to the ward, was more than the eastern parts (end of the ward). Figure 8 shows the possible spread of bacteria in some parts of the hospital.

According to the maps obtained from the spreading of bacteria in the intensive care unit (Fig. 8), the density of these microorganisms in the measured points located in the western part of the ward (entrance part) was more than the eastern parts (end of the ward). Due to the proximity of the entrance of the two infectious diseases and special care, the high presence of particles and bacteria in this area can be due to high traffic and lack of natural and artificial ventilation in this place.

The fungal spread distribution map in the intensive care unit shows that the rate of spread and dispersion of fungal aerosols was higher in the measuring points located in the western part and flow of pollutants had decreased while moving to the central and eastern (end of the ward). This situation indicated the concentration of fungi in the western part (entrance) of the intensive care unit. As mentioned above, the spread of bacteria was higher in the intensive care unit in the western part. Figure 9 shows the possible spread of fungi in some parts of the hospital.

One of the reasons for the high presence of pollutants at the entrance of the ICU can be the lack of proper and adequate ventilation in this area, as well as the high traffic of the 


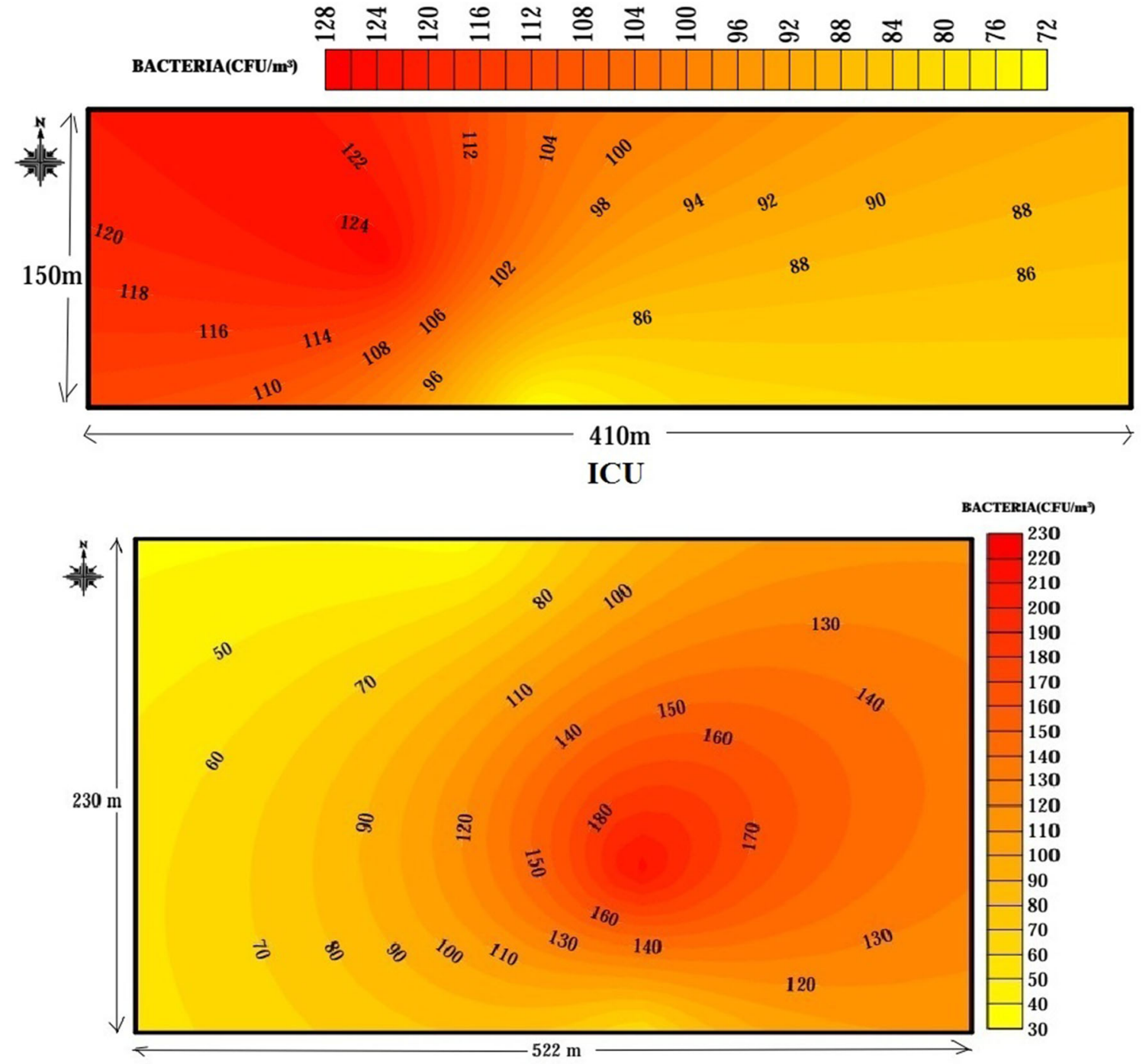

\section{Infectious}

Fig. 8 Possible dispersion of bacteria in each ward of the hospital

population and patients. On the other hand, in multibedroom wards of the hospital, including the intensive care unit, because there is a risk of infection of neighboring patients, reasonable measures should be taken to control the infection. In a study by Ching et al. carried out on reducing the risk of airborne infections in hospitals using hospital curtains, hospital curtains were called as physical barriers to disease transmission is potentially a simple but effective way to reduce the risk of infection; in this study, the effectiveness of hospital curtains in preventing the transmission of airborne diseases in hospital rooms has been investigated using numerical modeling. Among all case studies, it was found that the use of curtains between two beds can reduce the peak contaminant concentration for each neighboring patient in a bioaerosol dispersion process by up to $65 \%$ (Ching et al. 2008).

\section{Conclusion}

According to the results of differential tests and the molecular PCR test, most of the bacteria isolated from the air of the wards was Staphylococcus hemolyticus. It was found that the general average of the bioaerosols in the hospital was 184.38 CFU $/ \mathrm{m}^{3}$. The highest lowest densities of bioaerosols were in the lung $\left(336.67 \mathrm{CFU} / \mathrm{m}^{3}\right)$ and operating $(15.25 \mathrm{CFU} /$ $\mathrm{m}^{3}$ ) wards. Following that, the women's ward and then neurology had the highest pollutant density. Among the fungal species observed in the study, Penicillium, Cladosporium, Aspergillus Niger and Aspergillus Flavus were the most abundant, respectively. Similarly, Cladosporium, Penicillium and Aspergillus were found to be the dominant species isolated from hospital environments. It was found that there was no significant relationship between the number of particles 

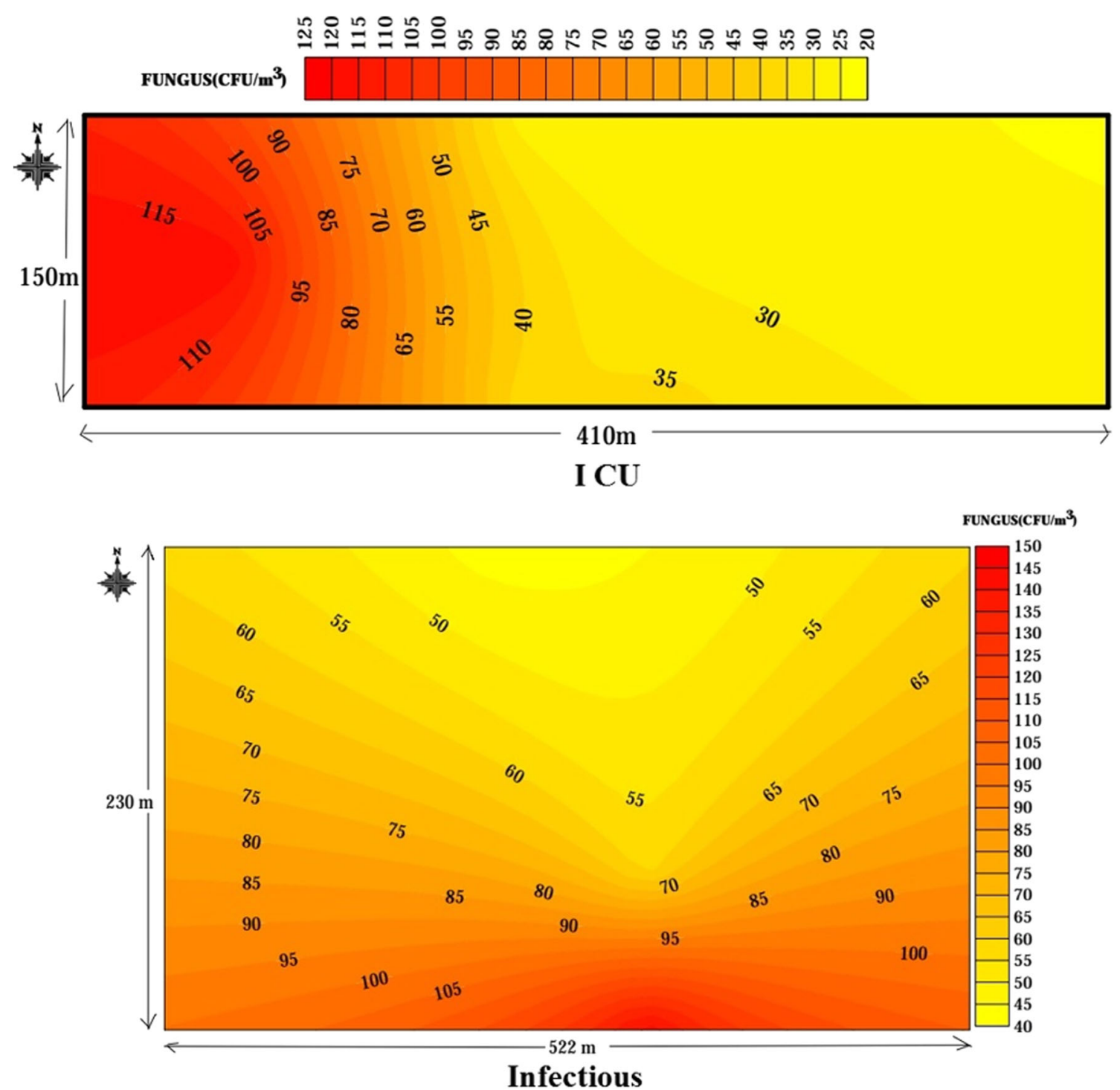

Fig. 9 Possible dispersion of fungi in the ICU of the hospital

observed in different sizes and concentrations and the number of bacteria observed. Based on antibiotic resistance of $18 \mathrm{com}-$ mon bacteria detected in this study, the highest drug resistance was observed in Staphylococcus hemolyticus and aureus. Staphylococcus hemolyticus showed resistance to five types of GM-CP-AZM-AMX-CFM antibiotics. It was found that the air quality in some wards of the hospital did not have a suitable status. Although the hospital benefits from a central ventilation system (exhaust fan), which covers all the wards, the system may suffer from a suitable operational and executive standard. Therefore, the system should be assessed closely in terms of principles of ventilation design. Since the Ecofan system and suction of inside air to outside and for ventilation and the entrance of fresh air to the inside, natural air without any pretreatment is used, thus, the quality of the inside air may be impacted and pollutants may be entered. Since the hospital lacks a suitable guideline and standard regarding the concentration of bacterial and fungal pollution inside the hospital air, it is vital to pay adequate attention to employ these standards by the responsible authorities. Most of the hospitals in Iran, like the hospital studied in the current research, lack a system for air treatment; therefore, enough equipment should be installed. Naturally, other affecting parameters like the standard of the number of beds to area, the physical sanitation of the hospital environment, optimum use of disinfectants, periodical disinfection of air flow path and channels to prevent microorganism growth and the training of staff should be taken into account. Although a complete evaluation and necessary analysis of the existing conditions was performed, a more comprehensive analysis of the situation is recommended in which other influential factors such as the effect of all seasons, working shift, temperature, relative humidity, number of people are taken into account. Risk assessment of bioaerosols is also recommended in future studies. 
Acknowledgements This article was extracted from the MSc dissertation of the first author. The authors would like to thank Kurdistan University of Medical Sciences and Environmental Health Research Center for its financial support provided for this research work (IR.MUK.REC.1397/ 226).

Author contribution AY-execution of the experiments and initial draft of the manuscript

$\mathrm{AM}$ - conceptualization, methodology, investigation, writing the original draft of manuscript

SD - methodology and analysis

ED - methodology and analysis

MA- experiments, analysis

EM- experiments, analysis

VTT - review and editing of the manuscript

RNK - methodology and analysis

HK - interpretation of data

Funding This study was funded by Kurdistan University of Medical Sciences and Environmental Health Research Center.

Data availability All data generated and analyzed during this study are included in this published article.

\section{Declarations}

Ethics approval and consent to participate Not applicable

Consent for publication Not applicable

Competing interests The authors declare no competing interests.

\section{References}

Aala F, Kohzadi S, Faridi A, Javan K, Amiri M, Ahmadnejad D, Khoubi J (2017) Monitoring the air fungal contamination load in two educational hospitals in Sanandaj, Iran. J Adv Environ Health Res 5: 233-240

Adabi M, Talebi Taher M, Arbabi L, Afshar M, Fathizadeh S, Minaeian S, Moghadam-Marageh N, Majidpour A (2015) Determination of antibiotic resistance pattern of Pseudomonas aeruginosa strains isolated from patients with burn wounds. Journal of Ardabil University of Medical Sciences 15:66-74

Alangaden GJ (2011) Nosocomial fungal infections: epidemiology, infection control, and prevention. Infect Dis Clin 25:201-225

Azizifar M, Jabbari H, Naddafi K, Nabizadeh R, Tabaraie Y, Solg A (2009) A qualitative and quantitative survey on air-transmitted fungal contamination in different wards of Kamkar Hospital in Qom, Iran, in 2007. Qom Univ Med Sci J 3

Cao C, Jiang W, Wang B, Fang J, Lang J, Tian G, Jiang J, Zhu TF (2014) Inhalable microorganisms in Beijing's PM2. 5 and PM10 pollutants during a severe smog event. Environ Sci Technol 48:1499-1507

Ching W-H, Leung M, Leung D, Li Y, Yuen P (2008) Reducing risk of airborne transmitted infection in hospitals by use of hospital curtains. Indoor Built Environ 17:252-259

Chinn RY, Sehulster L (2003) Guidelines for environmental infection control in health-care facilities; recommendations of CDC and Healthcare Infection Control Practices Advisory Committee (HICPAC).

Dadashi A, Firoozi F, Sanjarbeigi N, ZAHEDI NA, Amiri H, Nikooei M (2015) Prevalence and susceptibilities of Coagulase Negative
Staphylococci isolated in health care workers in a millitary hospital, Kermanshah. J Nurse Phys War 3:11-17

El-Sharkawy MF, Noweir ME (2014) Indoor air quality levels in a University Hospital in the Eastern Province of Saudi Arabia. J Fam Community Med 21:39-47

Fröhlich-Nowoisky J, Kampf CJ, Weber B, Huffman JA, Pöhlker C, Andreae MO, Lang-Yona N, Burrows SM, Gunthe SS, Elbert W (2016) Bioaerosols in the Earth system: Climate, health, and ecosystem interactions. Atmos Res 182:346-376

Gizaw Z, Gebrehiwot M, Yenew C (2016) High bacterial load of indoor air in hospital wards: the case of University of Gondar teaching hospital, Northwest Ethiopia. Multidiscip Respir Med 11:24

Goudarzi G, Soleimani Z, Sadeghinejad B, Alighardashi M, Latifi SM, Moradi M (2016) The impact of visiting hours on indoor to outdoor ratio of fungi concentration at university hospitals in Ahvaz, Iran. $\mathrm{J}$ Adv Environ Health Res 4:1-8

Gralton J, Tovey E, McLaws M-L, Rawlinson WD (2011) The role of particle size in aerosolised pathogen transmission: a review. J Infect 62:1-13

Kamali Sarwestani Z, Dasdar A, Agha Kuchak Afshari S, Gerami Shoar M, Hashemi SJ, Pakzad R, Ardi P, Abdollahi A, Haghi-Ashtiani MT, Mahmoudi S (2017) Evaluation of fungal air contamination in selected wards of two tertiary hospitals in Tehran, Iran. Tehran Univ Med J 75:299-306

Kim K-H, Kabir E, Jahan SA (2018) Airborne bioaerosols and their impact on human health. J Environ Sci 67:23-35

Kotgire S, Akhtar R, Damle A, Siddiqui S, Padekar H, Afreen U (2020) Bioaerosol assessment of indoor air in hospital wards from a tertiary care hospital. Indian J Microbiol Res 7:28-34

Krumins V, Mainelis G, Kerkhof LJ, Fennell DE (2014) Substratedependent rRNA production in an airborne bacterium. Environ Sci Technol Lett 1:376-381

Massoudinejad M, Ghajari A, Hezarkhani N, Aliyari A (2014) Survey of Environmental Bioaerosols in ICU ward of Taleghani Hospital in Tehran by Petri-dish trapping technique and Bioaerosol Sampler in 2013. J Safety Promot Inj Prev 2:133-139

Massoudinejad MR, Ghajari A, Hezarkhani N, Aliyari A (2015) Survey of Fungi Bioaerosols in ICU ward of Taleghani Hospital in Tehran by Petri-dish trapping technique and Bioaerosol Sampler in 2013. Irtiqā-yi īminī va pīshgīrī az mașdūmiyat/ha (ie, Safety Promotion and Injury Prevention) 3, 147-154

Mirhoseini SH, Nikaeen M, Khanahmad H, Hatamzadeh M, Hassanzadeh A (2015) Monitoring of airborne bacteria and aerosols in different wards of hospitals-Particle counting usefulness in investigation of airborne bacteria. Ann Agric Environ Med 22:670-673

Mirhoseini SH, Nikaeen M, Khanahmad H, Hassanzadeh A (2016) Occurrence of airborne vancomycin-and gentamicin-resistant bacteria in various hospital wards in Isfahan, Iran. Adv Biomed Res 5

Mousavi MS, Hadei M, Majlesi M, Hopke PK, Yarahmadi M, Emam B, Kermani M, Shahsavani A (2019) Investigating the effect of several factors on concentrations of bioaerosols in a well-ventilated hospital environment. Environ Monit Assess 191:407

Mulla SI, Hu A, Sun Q, Li J, Suanon F, Ashfaq M, Yu C-P (2018) Biodegradation of sulfamethoxazole in bacteria from three different origins. J Environ Manag 206:93-102

Naddafi K, Rezaei S, Nabizadeh R, Younesian M, Jabbari H (2009) Density of Airborne Bacteria in a Children Hospital in Tehran. Iranian J Health Environ 1:75-80

Najotra DK, Malhotra AS, Slathia P, Raina S, Dhar A (2017) Microbiological surveillance of operation theatres: Five year retrospective analysis from a Tertiary Care Hospital in North India. Int J Appl Basic Med Res 7:165-168

Nikaido H (2009) Multidrug resistance in bacteria. Annu Rev Biochem 78:119-146

Nunes ZG, Martins AS, Altoe ALF, Nishikawa MM, Leite MO, Aguiar PF, Fracalanzza SEL (2005) Indoor air microbiological evaluation 
of offices, hospitals, industries, and shopping centers. Mem Inst Oswaldo Cruz 100:351-357

Osadebe AU, Okounim B (2020) Multidrug-resistant bacteria in the wastewater of the hospitals in Port Harcourt metropolis: Implications for environmental health. J Adv Environ Health Res 8:46-55

Park D-U, Yeom J-K, Lee WJ, Lee K-M (2013) Assessment of the levels of airborne bacteria, gram-negative bacteria, and fungi in hospital lobbies. Int J Environ Res Public Health 10:541-555

Rafiee A, Hoseini M, Shabani H, Shahedi A (2018) Assessment of the density and type of the bio-aerosols associated with nosocomial infection in different wards of the selective AJA hospitals in Tehran. EBNESINA 19:45-52

Saadat S, Solhjoo K, Norouz-nejadfard MJ, Kazemi A, Rouhi R, Mardaneh J (2014) The frequency of Staphylococcus aureus among Shiraz hospital personnel and determination of their antibiotic sensitivity pattern. ISMJ 17:916-926

Saadoun I, Al Tayyar IA, Elnasser Z (2008) Concentrations of airborne fungal contaminations in the medical surgery operation theaters (OT) of different hospitals in northern Jordan. Jordan J Biol Sci 1: 181-184

Saha B, Singh AK, Ghosh A, Bal M (2008) Identification and characterization of a vancomycin-resistant Staphylococcus aureus isolated from Kolkata (South Asia). J Med Microbiol 57:72-79

Sautour M, Sixt N, Dalle F, l'Ollivier C, Fourquenet V, Calinon C, Paul K, Valvin S, Maurel A, Aho S (2009) Profiles and seasonal distribution of airborne fungi in indoor and outdoor environments at a French hospital. Sci Total Environ 407:3766-3771

Sepahvand A, Godini H, Omidi Y, Tarrahi M, Rashidi R, Basiri H (2016) Investigation of fungal bioaerosols and particulate matter in the teaching-medical hospitals of Khorramabad City, Iran during 2015. Iranian J Health Environ 9:115-126

Shokri S, Nikpey A, Varyani AS (2016) Evaluation of hospital wards indoor air quality: the particles concentration. J Air Pollutt Health 1: 205-214
Sivagnanasundaram P, Amarasekara R, Madegedara R, Ekanayake A, Magana-Arachchi D (2019) Assessment of Airborne Bacterial and Fungal Communities in Selected Areas of Teaching Hospital, Kandy, Sri Lanka. BioMed Research International 2019

Solomon FB, Wadilo FW, Arota AA, Abraham YL (2017) Antibiotic resistant airborne bacteria and their multidrug resistance pattern at University teaching referral Hospital in South Ethiopia. Ann Clin Microbiol Antimicrob 16:1-7

Thompson JD (1994) Improving the sensitivity of progressive multiple sequence alignment through sequence weighting, position-specific gap penalties and weight matrix choice. Nucleic Acids Res 22: 4673-4680

Valedeyni AF, Hazrati S, Arzanlou M, Fazlzadeh M (2018) ASSESSMENT OF BACTERIAL BIO-AEROSOLS TYPES AND ITS CONCENTRATION IN THE AMBIENT AIR OF EDUCATIONAL HOSPITALS OF ARDABIL UNIVERSITY OF MEDICAL SCIENCES IN 2016.

Verde SC, Almeida SM, Matos J, Guerreiro D, Meneses M, Faria T, Botelho D, Santos M, Viegas C (2015) Microbiological assessment of indoor air quality at different hospital sites. Res Microbiol 166: $557-563$

Vonberg RP, Gastmeier P (2006) Nosocomial aspergillosis in outbreak settings. J Hosp Infect 63:246-254

Wang X, Bi X, Sheng G, Fu J (2006) Hospital indoor PM10/PM2. 5 and associated trace elements in Guangzhou, China. Sci Total Environ 366:124-135

Wéry N (2014) Bioaerosols from composting facilities - A review. Front Cell Infect Microbiol 4: 1-9

Publisher's note Springer Nature remains neutral with regard to jurisdictional claims in published maps and institutional affiliations. 